\title{
A PRISÃO DE PEDRO IVO E O DEBATE POLITICO APÓS A PRAIEIRA, 1849-1854
}

Estrada do Caminho Velho, 333 07252-312 - Guarulhos - São Paulo mlfoliveira@hotmail.com
- Maria Luiza Ferreira de Oliveira*

Universidade Federal de São Paulo

Guarulhos - São Paulo - Brasil

\section{Resumo}

Nesse artigo reconstituímos a ampla e quase desconhecida polêmica em torno da prisão de Pedro Ivo em maio de 1850 no Rio de Janeiro. Depois procuramos esclarecer o teor do debate político do tempo, ressaltando a força da bandeira por uma Assembleia Constituinte, encampada por mais de uma dezena de periódicos liberais. Seguimos acompanhando o impacto da fuga de Pedro Ivo, o grandioso banquete da "regeneração nacional" e a repentina morte, eventos que marcaram o imaginário da época. Os eventos repercutiram inclusive entre os povos das matas de Alagoas, por isso abordamos a reação do diretor da Colônia Militar e o esforço de "desinfestação" do território. Estava em pauta uma disputa de narrativas, tanto da atuação de Pedro Ivo, bandido ou herói, como da própria memória da Rebelião Praieira. Ao mesmo tempo, havia naqueles anos diferentes projetos de futuro para o país.

\section{Palavras-chave}

Liberais - saquaremas - Praieira - Assembleia Constituinte - imprensa política.

* Doutora pelo Programa de Pós-Graduação em História Social do Departamento de História da Faculdade de Filosofia, Letras e Ciências Humanas da Universidade de São Paulo. Desde 2008 é professora no Departamento de História da Universidade Federal de São Paulo, atuando também na pós-graduação. 


\title{
THE ARREST OF PEDRO IVO AND THE POLITICAL DEBATE AFTER THE PRAIEIRA, $1849-1854$
}

Estrada do Caminho Velho, 333 07252-312 - Guarulhos - São Paulo mlfoliveira@hotmail.com

\section{- Maria Luiza Ferreira de Oliveira}

Universidade Federal de São Paulo

Guarulhos - São Paulo - Brazil

\begin{abstract}
In this paper, we revisited the great and nearly unknown controversy about Pedro Ivo's imprisonment in May 1850 in Rio de Janeiro. Then, we attempted to clarify the content of the political debate at that time, pointing out the strength of the struggle for a Constituent Assembly, advocated by over a dozen liberal periodicals. We continue by examining the impact of Pedro Ivo's escape, the great banquet of the "national regeneration" and his sudden death, events that marked the current imagination. Such events had repercussions even among the peoples living in the woods of Alagoas, and because of this we discuss the reaction of the Military Colony director and the effort to "disinfest" the territory. A dispute of narratives existed, both of the performance of Pedro Ivo either as a bandit or as hero, and of the own memory of the Praieira Revolt. There were also different and simultaneous projects of future for Brazil in those years.
\end{abstract}

\section{Keywords}

Liberals - saquaremas - Praieira Revolt - Constituent Assembly - political press. 
A oposição tem procurado fazer de Pedro Ivo mais que um Napoleão (...) como se da sua espada dependesse os destinos desse império. Justiniano José da Rocha, junho de 1850.

Pedro Ivo Velloso da Silveira foi preso na fortaleza de Santa Cruz no Rio de Janeiro em maio de 1850. Em julho, correu o boato de que havia um plano de fuga. Quem divulgou o plano, alarmado, foi ninguém menos do que o imperador d. Pedro II, em uma carta pessoal para Paulino José Soares de Souza, na época ministro das Relações Estrangeiras:

...de noite, quando todos se recolhem, a um sinal, que será a retirada da luz do quarto de Pedro Ivo se há de lançar uma corda da muralha da fortaleza para um bote que deve atracar ao argolão do desembarque (...) talvez o que digo não passe d'uma história ou de mera suposição.

No final da carta, d. Pedro II explicitou o motivo de sua apreensão e deu sugestões específicas de encaminhamento:

...parece que os prezos tem em vista ir à Bahia empregar o único meio que pode surtir como efeito verdadeiramente atterrador que é o Açulamento do baxo povo, ou melhor uma revolução social. Escuso dizer - mas toda guarnição de Santa Cruz merece ser vigiada incessantemente. ${ }^{1}$

\section{Narrativas em disputa}

Chama a atenção do leitor a preocupação do monarca com a possível fuga de Pedro Ivo e a dimensão que atribuía àqueles homens, àquele evento. Junto com Pedro Ivo estavam presos companheiros de trincheira, Miguel Affonso, Batinga e o cadete Falcão. Eles estariam aptos para "açular" o povo, ou seja, eram líderes políticos relevantes, teriam ouvintes capazes de pegar em armas para buscar promover "uma revolução social", no vocabulário atualizado por d. Pedro II ao correr da pena.

1 D. Pedro II. Carta do imperador. 1850. Instituto Histórico e Geográfico Brasileiro, doravante IHGB. Arquivo Visconde Uruguai, DL 04,12. 
Mas, afinal, o que teriam feito aqueles homens para merecer tal receio, tirando o sossego do imperador? E, mais, estaria d. Pedro II sendo excessivamente temeroso? Na edição de 8 de janeiro de 1850 do jornal $O$ Brasil, lia-se que o grupo de Pedro Ivo era perigoso pois "a vida e a fortuna dos cidadãos" estavam sendo "postas em risco pelos comunistas do sertão".2 Tal caracterização causaria provavelmente espanto até no próprio Pedro Ivo. Os leitores da época podem ter estranhado, pois já conheciam, de edições anteriores, a opinião do jornal sobre Pedro Ivo - era alguém que não "se armava por princípios políticos", era um desertor, um "bandido promotor da anarchia". Mas se fossem leitores de outros periódicos como O Correio Mercantil, saberiam tratarse de "hábil guerreiro", líder da Rebelião Praieira, líder dos liberais. Ao longo de 1849 e de 1850 foram muitas as matérias na imprensa tanto nos principais jornais da Corte, como O Brasil, o Correio Mercantil e o Diário do Rio de Janeiro, como nos jornais de Pernambuco, Maranhão, Pará, Minas Gerais, Espírito Santo, Ceará, Rio Grande do Sul. ${ }^{3}$ Pedro Ivo era conhecido nacionalmente.

Nascido em 1811 em Olinda, foi alistado ainda menino, aos onze anos, no período da independência. ${ }^{4}$ A sua primeira guerra foi no Ceará, para onde viajou em junho de 1832 - a revolta de Pinto Madeira. Dali desceu, no final desse ano, destacado para Panelas de Miranda no agreste pernambucano para lutar na Guerra dos Cabanos, onde ficou por três anos. Saiu do acampamento de Panelas para as matas do Pará, enviado para lutar na Cabanagem em outubro de 1835. Era tenente quando, aos 27 anos, foi para a Expedição do "Alto e baixo Amazonas" em 1837. Ficou sete anos entre índios, caboclos e tropas, vivendo a maior parte do tempo pela floresta. Voltou para Pernambuco só no início de 1842, já com 31 anos e feito capitão. Em 1843, enfrentou sua primeira prisão por ter publicado uma nota no jornal Diário Novo criticando a atitude despótica do comandante. O jornal praieiro fez matérias defendendo o "bravo capitão". No final de 1843, foi para o Rio de Janeiro em diligência, voltando em junho de 1844 para o Recife. Participava também da

2 O Brasil. Rio de Janeiro, 8/1/1850, p. 2. Itálico no original.

3 Ver, por exemplo, O Cearense (CE); Correio da Victoria (ES); O Telegrapho (MA); Publicador Maranhense (MA); Treze de maio (PA); O Imparcial (RS); O Rio-grandense (RS); Correio Sergipense (SE); O Mercantil (MG); O Itamontano (MG); A Voz da Verdade (PI); O Meteoro (SP); O Piratininga (SP) - alguns dos jornais que repercutiram notícias e publicaram análises sobre Pedro Ivo.

4 Arquivo Histórico do Exército, doravante AHEX. Fé de Ofício, pasta VI / 9/ 106. Era filho do major Pedro Antonio Velloso da Silveira. Em informe vindo da província do Pará de 1837, foi anotado em sua ficha: "tem 27 anos, não he relaxado, he activo e laborioso, não está instruído suficientemente, não tem nota em desabono". Tinha cabelos castanhos, olhos pardos. Cf. OLIVEIRA, Maria Luiza Ferreira. As guerras nas matas de Jacuípe. Revista Clio, n. 33.2, Recife, UFPE, 2015. 
vida cívica: em setembro de 1844 foi dos eleitores mais votados na freguesia de Boa Vista, no Recife, com 1.429 votos, ajudando na vitória dos praieiros. ${ }^{5}$ Lutou em Maceió, no esforço de retomar a capital para o governo e tirar o presidente do navio fundeado na costa, na rebelião de 1844, tendo sido elogiado nos jornais pela sua atuação e "bravura". No ano seguinte, foi destacado para a Guerra do Jacuípe nas matas de Alagoas.

Em março de 1848, Pedro Ivo escreveu de Água Preta avisando o governo que os conservadores "apresentarão a revolução em campo". 6 O engenho do tio de Pedro Ivo, José Pedro Velloso da Silveira, seria o bastião dos revoltosos. Fortificado, "o castelo feudal" juntava todas as forças dos insatisfeitos senhores de engenho - diziam ser 1.000 homens. A revolta foi armada buscando derrubar o governo liberal em Pernambuco. Ali a luta foi dura, muitos morreram. ${ }^{7}$ Pedro Ivo não estava na mesma trincheira do tio, ainda não seria dessa vez que lutaria contra o governo.

Foi nesse ano, em 1848, que Pedro Ivo tirou três meses de licença do serviço, ao final da qual não se apresentou. Era a Praieira que começava. ${ }^{8}$ No

\footnotetext{
${ }^{5}$ Diário Novo. Recife, 27.11.1844, p. 3. O jornal publicou a lista de todos os eleitores praieiros "vencemos completamente a eleição".

${ }^{6}$ O presidente de Alagoas enviou a carta de Pedro Ivo ao presidente de Pernambuco, Chichorro da Gama. 8/03/1848. Arquivo Público Estadual de Pernambuco Jordão Emerenciano, doravante Apeje. Pedro Ivo Velloso da Silveira. PP 20, fl. 91 e seguintes.

7 Houve um confronto no engenho Lages no dia 18 de abril de 1848 com as tropas do governo comandadas por Antônio Feijó de Melo, com 350 homens. Depois de duas horas de pesado fogo, o comandante do governo recuou, uma vez que o reforço que esperava não veio. A revolta guabiru arrefeceu com a saída de Chichorro da Gama do governo em 20 de abril para assumir cadeira de deputado. O vice-presidente procurou conciliar com os conservadores, mudou o comandante de armas e negociou cessar fogo. Ver MOSHER, Jeffrey C. Political struggle, ideology and state building, Pernambuco and the construction of Brazil, 1817-1850. Lincoln: University of Nebraska Press, 2008, p. 209-214.

8 A bibliografia sobre a Praieira é ampla, embora a trajetória de Pedro Ivo tenha sido menos visitada pelos historiadores. O artigo de Marcus Carvalho trouxe à tona a questão da participação das lideranças populares naqueles anos e falou da potência de Pedro Ivo, sinalizando a coexistência de várias lutas e expectativas. Cf. CARVALHO, Marcus. Os nomes da Revolução: lideranças populares na Insurreição Praieira, Recife, 1848-1849. Revista Brasileira de História, vol. 23, n. 45, São Paulo, 2003, p. 209-238. Amaro Quintas deu relevo às demandas dos liberais, sobretudo em QUINTAS, Amaro. O sentido social da Revolução Praieira. Recife: Massangana, 1982. Ver também QUINTAS, Amaro. O Nordeste, 1825-1850. In: HOLANDA, Sérgio Buarque de (org.). História geral da civilização brasileira, tomo II-2. São Paulo: Difel, 1985, p. 193-241. A pesquisa de Jeffrey Mosher, já citada, é também referência, voltando a 1817 para entender com mais profundidade as posições ideológicas em campo. Izabel Marson é autora de um dos estudos clássicos que transformaram a leitura da revolta, sobretudo por redimensionar os embates ideológicos. Cf. MARSON, Isabel. O Império do progresso, a Revolução Praieira em Pernambuco, 18421855. São Paulo: Brasiliense, 1987.
} 
quartel general do Exército Liberal em Água Preta, decidiu-se que o Exército teria três divisões, cada uma com duas brigadas, sendo cada brigada com quatro batalhões. Pedro Ivo Velloso da Silveira era comandante da $2^{\text {a }}$ divisão, com o posto de brigadeiro. Comandavam as outras duas divisões João Ignacio Ribeiro Roma e Bernardo José da Camara.9 Assim, o Exército liberal tinha por brigadeiros um militar com ampla experiência de campo, um senhor de engenho e um líder político histórico, João Ignacio Ribeiro Roma, participante da Confederação do Equador e filho do mártir de 1817, o padre Roma. Caetano Alves, guerreiro popular e o principal parceiro de Pedro Ivo, estava sob as suas ordens, comandando um dos batalhões da $2^{\text {a }}$ divisão. Também lutavam com Pedro Ivo os índios de Barreiros.

Pedro Ivo liderou uma das colunas que invadiu a cidade do Recife em 2 de fevereiro de 1849. Ao final do dia, depois de tantos tombarem, retirouse com seus homens para as matas. Viria uma difícil guerra envolvendo centenas de combatentes e mobilizando redobrados esforços sobretudo da presidência de Pernambuco.

Os métodos de combate na guerra não foram apenas as armas. Honório Leão tentou negociar anistia para Pedro Ivo através do general Coelho, mas o capitão queria anistia para todos os envolvidos na revolta, incluindo os que se achavam presos..$^{10}$ Em carta, Pedro Ivo declarou ainda que ofereceram dinheiro para ele largar as armas, o que não fez por "ser improprio de um caracter".11 Honório Leão não quis conceder anistia geral e sem condições. Decidiu endurecer ao publicar em novembro de 1849 a resolução:

O presidente da província considerando que os grupos reunidos nas matas do sul, debaixo do comando de Caetano Alves da Silva e do capitão Pedro Ivo Velloso da Silveira (...) não tem caracter algum político; (...) resolve: Art. $1^{\circ}$ Todas as pessoas que derem favor e ajuda (...) serão considerados complices de taes crimes (...) Art. $3^{\circ}$ Os habitantes das matas do sul (...) desta província, que não quiserem compartilhar a sorte dos referidos bandidos, deverão retirar-se das matas até ao fim do corrente mez, apresentando-se ao comandante das armas (...) Art. $4^{\circ}$ As guerrilhas que prenderem a qualquer dos

\footnotetext{
9 Documento publicado por MELLO, Jeronimo Martiniano Figueira de. Chronica da Rebelião Praieira em 1848 e 1849. Rio de Janeiro: Typ. do Brasil de J. J. da Rocha, 1850, p. 268.

${ }^{10}$ Entre os jornais que publicaram sobre as negociações de anistia ver O Itamontano (MG), 23/01/1850, p. 2.

${ }^{11}$ Carta de Pedro Ivo entregue pelo frei capuchinho Euzebio de Salles ao presidente de Alagoas, endereçada a Honório Leão. O missionário esteve com Pedro Ivo tentando persuadi-lo a largar as armas. Carta escrita em Martins, 15/09/1849. Correspondência da presidência de Alagoas ao Ministério da Guerra. Arquivo Nacional do Rio de Janeiro, doravante ANRJ, IG (1) 97, 1846-1849.
} 
chefes Caetano Alves ou o capitão Pedro Ivo, receberão uma gratificação e premio de oito contos de réis, e no caso se serem os ditos chefes mortos em acto de resistência, receberão quatro contos de réis. ${ }^{12}$

Os liberais nomearam o ato de Honório Leão de decreto de sangue ${ }^{13}$ e vociferaram nos diversos jornais do país. A contrapartida também se fez presente. A matéria de primeira página do jornal O Brasil no Rio de Janeiro, vinte dias depois da publicação do decreto no Recife, já defendia o líder conservador, trazendo um título ousado, Cabeças a prêmio, o ponto central que motivara a fúria dos liberais. A matéria procurava defender a legalidade da decisão de Honório Leão. Diferenciava essa batalha da Praieira, afirmando que "o movimento político cessou", agora eram apenas "homens ferozes que resistiram ao mais amplo e generoso perdão". Defendia a necessidade de medidas severas: era preciso um pouco de "vigor e de energia" para buscar a "pacificação". Sobre o prêmio em dinheiro, Justiniano argumentou que era recurso comum da polícia, usado inclusive em outros lugares, como "recentemente na Inglaterra". ${ }^{4}$ Para discutir o argumento moral, desafiava: "quem diz que será a cobiça, que não o patriotismo, que com esse convite se decida?". ${ }^{5}$

Em Fortaleza, lia-se na primeira página do periódico liberal $O$ Cearense, no dia 17 de dezembro de 1849, os versos de um poema transcrito do jornal baiano $O$ Século:

\footnotetext{
${ }^{12}$ Resolução publicada no Diário de Pernambuco, parte oficial, governo da província, edição n. 252, sábado 10/11/1849. O debate com a discussão do impacto da lei de Honório Leão também está no artigo: OLIVEIRA, Maria Luiza F. Circulação de saberes e de práticas governativas: caminhos de articulação da política no Brasil, 1845-1860. Almanack, n. 18, Guarulhos, abr. 2018, p. 255/256.

${ }^{13}$ Correio Mercantil. Rio de Janeiro, 25/11/1849. “Um governo sem respeito à lei, à moral, à religião...tenhão nossos amigos resignação, valor e constância, que a patria sera salva...tanto mais o governo abusar do poder, violar a constituição e as leis do país, mais se aproximará de sua ruina". Além do prêmio em dinheiro para o assassinato, causou profunda indignação proclamarem réus de crimes os companheiros de Pedro Ivo sem terem sido julgados e ainda obrigar os habitantes das matas a deixarem suas casas.

${ }^{14} O$ Brasil. Rio de Janeiro, 29/11/1849.

${ }^{15} \mathrm{O}$ Brasil. Rio de Janeiro, 10/02/1850, domingo. O debate foi intenso e violento - o Correio Mercantil dedicou várias edições ao tema, inclusive reproduzindo debates da Câmara. Uma das matérias intitulava-se "O despotismo posto em ação e arvorado em doutrina".
} 


\author{
Que cynismo! Que crueza! \\ Oh que infâmia! Que fraquesa! \\ Estremece a natureza, \\ Escutando um tal pregão! \\ (...) \\ Armando assassina mão, \\ Presume o homem leão \\ Frustrar decretos de Deus! \\ A quem trouxer, morto ou vivo \\ O guerreiro Pedro Ivo \\ Marca o preço - e decisivo \\ Considera um meio tal! \\ Mas assim não ha de ser \\ Nem o Brasil assim ver \\ Seu Garibaldi morrer. ${ }^{16}$
}

No dia 29 de dezembro de 1849, o Correio Mercantil, principal jornal da oposição, divulgaria a resposta dos próprios revoltosos ao decreto. Os habitantes do Rio de Janeiro puderam ler trechos de uma carta assinada por Pedro Ivo e Caetano Alves. Começavam por chamar Carneiro Leão de ditador, explicando que a causa deles era a da "liberdade contra a tyrania":

A coluna d'Agua Preta tem um caráter político, e esse tão nobre e elevado...nos querem reduzir a triste condição dos infelizes Polacos. Não o conseguirão....A constituinte é pois quem pode salvar o Brasil e pela sua convocação verteremos a ultima gota de sangue. Homens que nutrem tão nobres sentimentos não são assassinos, não são salteadores....17

O Século na Bahia foi o jornal que recebeu a carta pedindo a publicação, pois, como justificaram os autores, "em Pernambuco a imprensa oposicionista deixou de existir". Não ficamos sabendo, contudo, quais as conexões dos autores com a Bahia, quem se encarregou de intermediar o envio e a publicação do manifesto. Vale lembrar que o boato divulgado por d. Pedro II

\footnotetext{
${ }^{16}$ O Cearense. Fortaleza, 17/12/1849, ano IV, n. 293. O poema tinha o título O brado do trovador. É bem maior e vinha assinado "pelo auctor da Sombra do Martyr, Do Século".

${ }^{17}$ Correio Mercantil. Rio de Janeiro, 29/12/1849. Também havia na carta a preocupação de esclarecer que "a força sob o commando dos abaixo assinados não praticou um só roubo, uma só depredação e um só assassino. O conselheiro Honório, emprestando-lhe semelhantes crimes, está na rigorosa obrigação de especificar os factos e prova-los: (...) O ouro (bem sabe o presidente) nunca comprou, não compra e nem comprará os abaixo assinados; porque apreciao mais a sua honra (...) respeitamos as vidas dos infelizes que ficarão feridos (...)".
} 
previa que depois da fuga seria na Bahia que Pedro Ivo procuraria promover "a revolução social".

De toda maneira, a acusação sobre a imprensa em Pernambuco era fundamentada. Quando Manuel Vieira Tosta entregou o governo para Honório Leão avisou que, apesar dos esforços da imprensa para advogar "a causa perdida da revolta, hei-lhes frustrado os planos, como informará a V. Excia o Chefe de Polícia", e em seguida contou uma das medidas que tomara:

...há quatro dias, sabendo que o Tenente da 3a. Classe João Marinho de Albuquerque Cavalcante ouzava servir de responsável a uma typographia com a denominação de Liberal dei ordem ao Comandante das armas para o mandar embarcar para a Corte. ${ }^{18}$

O esforço de controle vinha desde o começo do ano. Em janeiro de 1849, o Correio Mercantil denunciava, no Rio de Janeiro, os "attentados contra a imprensa" no Recife. A polícia tinha mandado chamar os compositores da tipografia do Diário Novo, prometendo "pagar-lhe os jornais se abandonassem o estabelecimento" e, dias depois, um destacamento policial cercou a tipografia para prender um tipógrafo, pressionando a viúva Umbelina ${ }^{19}$ que se recusou a abrir as portas, causando comoção no bairro. Os métodos de controle eram diversificados. Honório Leão teve 18 contos para despesas secretas da "pacificação", dinheiro para espionagem, gratificações diversas, incluindo "pagar o silêncio da imprensa da viúva Roma". ${ }^{20}$ Ele declarou que negociou com a viúva uma gratificação e a circulação do Diário Novo foi suspensa, mas por pouco tempo. Logo a tipografia retomaria a impressão de folhetos e outros jornais liberais. Seria impresso nessa tipografia o radical A Revolução de Novembro que circulou de agosto de 1850 até dezembro de 1852. O primeiro diretor da folha "do povo contra o poder" denunciou no jornal as violências policiais e as ameaças que faziam constantemente à senhora viúva Roma para que desistisse da empresa.

\footnotetext{
${ }^{18}$ Manuel Vieira Tosta para Honório Carneiro Leão. Correspondência reservada. 2/07/1849. Ministério do Império. ANRJ, IJJ (9) 253.

${ }^{19}$ A viúva Roma, ou dona Umbelina Coelho da Silva Roma, tornou-se viúva de Luiz Ignacio Ribeiro Roma, proprietário da Typographia Imparcial e um dos fundadores do Diário Novo. Ela assumiu a direção da empresa que passou a se chamar Typographia da Viúva Roma \& Filhos. NASCIMENTO, Luiz do. História da imprensa de Pernambuco (1821-1954). Recife: Universidade Federal de Pernambuco, Editora Universitária, 1966.

${ }^{20}$ Honório Leão para José Ildefonso S. Ramos. Correspondência reservada. 18/05/1850. Ministério da Justiça. ANRJ, IJ824.
} 
Outro jornal radical no Rio de Janeiro, $O$ Grito Nacional, publicou a carta de Pedro Ivo e Caetano Alves na íntegra na edição de $1^{\circ}$ de janeiro de 1850 - dizendo que seria "esse o ano em que veremos a Liberdade esmagar o despotismo". O Diário do Rio de Janeiro respondeu no dia seguinte, na primeira página, pelo articulista "O Brasileiro". Cheio de ironia, buscou desqualificar os argumentos dos autores do manifesto, pois não passariam de criminosos travestidos de heróis. Poucos dias depois, O Brazil transcreveu a crítica do Diário, enfatizando o argumento de que a oposição perdia o rumo dando espaço para o "desertor Pedro Ivo".

E foi também no primeiro dia do ano, na frente de toda a Assembleia, assim como das galerias lotadas, que d. Pedro II, na Fala do Trono, referiuse aos conflitos em Pernambuco, "os homens perdidos, que, surdos à voz da minha imperial clemência (...) procuram novamente perturbar a tranquilidade publica. O meu governo continua a empregar meios enérgicos para extinguir este gérmen revolucionário". ${ }^{21}$ Qualificou, assim como já tinha feito Justiniano José da Rocha, como enérgica a ação do governo e chamou de "perdidos" aos que estavam em armas. Atribuiu ao movimento uma dimensão revolucionária, impressão que ecoaria alguns meses depois na carta a Paulino Soares de Souza, quando se preocupou com a fuga de Pedro Ivo.

A chancela final a favor de Honório Leão veio do próprio imperador. A Fala do Trono, além de apoiar os meios enérgicos, classificando como crime ao invés de luta política o que ocorria em Pernambuco, ainda pedia "a necessidade de providencias que habilitem o governo a augmentar a força do exército e marinha e lhes dê organisação mais regular e vigorosa". O teor da fala foi também motivo de aguerrido debate na imprensa. Os liberais ficaram indignados:

...como pode o monarcha chamar perdidos a uma parte de seus súbditos? (...) os juízes que tem de julgar os crimes não podem antecipar opinião (...) como o poderá fazer o chefe do estado? (...) semelhante linguagem é uma infração violenta dos princípios constitucionais.22

O jornal O Itamontano de Minas Gerais abordou o tema detidamente, em inúmeras edições. Os redatores também fizeram piada, quando, por

\footnotetext{
${ }^{21}$ Fallas do Trono desde o anno de 1823 até o anno de 1889. Rio de Janeiro: Imprensa Nacional, 1889 , p. 439/440.

${ }^{22}$ Correio Mercantil. Rio de Janeiro, 9/01/1850. Na mesma edição, no setor internacional, aparecia a dimensão ampla do processo: "A ordem reina.... em Guns, doze magyares são condenados à
} 
exemplo, disseram que o ministro Tosta (a quem atribuíam a autoria do discurso do imperador) tinha razão ao chamar de perdidos os revoltosos da mata de Pernambuco: "perdidos sim, porque o governo os não pode achar para fazer-lhes a amabilidade de guilhotiná-los". ${ }^{23}$ Em meados de fevereiro, transcreveram um longo trecho do discurso do senador liberal Paula Souza: "se há de sufocar o espirito do tempo só com a força bruta? Acaso as ideas vencem-se com canhões? Não é possível. Eu quero que as revoltas sejao extirpadas, mas que se extirpem também as causas que as produzem". Pedia reformas, dizia que o Brasil precisava de esperança já que estava "sob compressão", e terminava afirmando que "só as ideias consolidão as cousas; o governo intervém em tudo, exerce a mais violenta ditadura (...) eis porque não aprovo a fala do throno (...) julga-se tudo ótimo, quer-se só força e mais força e nada de reformas". ${ }^{24}$

Abertos os trabalhos na Assembleia, o debate sobre o decreto de Honório Leão que vinha sendo feito pela imprensa tomou conta do plenário. O deputado liberal Souza Franco acusava o desrespeito à Constituição, o deputado Nabuco Araújo defendia a atitude de Honório Leão. O editor do Correio Mercantil comentou os debates nas duas câmaras: "para reprimir os que se insurgem contra o governo ou a lei é lícito ao governo por sua vez rebelar-se contra a constituição: o que da parte da oposição é desregramento, quando praticado pelo ministério é moderação". ${ }^{25}$ Honório Leão teve apoio de ministros importantes; em fevereiro, escreveu uma carta pessoal agradecendo, comovido, o apoio que o ministro Paulino lhe confiara em discurso na tribuna. ${ }^{26}$

Em fevereiro de 1850, o jornal Diário de Pernambuco publicaria trechos de uma espécie de diário de guerra feito por um major das forças liberais, Laurindo Justiniano de Alexandria e Mello. No texto, apreendido pelos legalistas, há informações sobre o percurso que tinham feito, as ordens dadas para cada quartel, a organização dos homens, mostrando uma grande quantidade

morte e enforcados. Foi suprimido em Viena um jornal moderno, o Tempo, porque em artigo censurara a aplicação de pauladas e varadas actualmente em uso na Áustria para todos os delitos políticos".

${ }^{23}$ O Itamontano. Ouro Preto, 6/02/1850. Na primeira edição dedicada ao tema, os redatores julgaram que tinha "escurecido o horizonte do paiz"; em outro dia, também usaram uma imagem forte, a política atual ia conseguir "o silêncio dos túmulos".

${ }^{24}$ O Itamontano. Ouro Preto, 13/02/1850.

${ }^{25}$ Correio Mercantil. Rio de Janeiro, 22/01/1850. O jornal publicou os debates da sessão no dia anterior.

${ }^{26}$ Honório Carneiro Leão. 16.02.1850. Carta. IHGB, Coleção Visconde de Uruguai. Ele frisou: “... assegurar-lhe que se acha gravado em minha memoria a parte do discurso que VE fez perante o Senado contendo a defesa dos meus atos como presidente desta Provincia". 
de oficiais envolvidos (nessa altura eram 25, entre eles Miguel Affonso Ferreira, que seria preso com Pedro Ivo). Fica patente o considerável esforço de guerra. O autor do diário escreveu sobre a vitória na tomada da povoação de Capoeiras no dia 4 de janeiro, "cobardemente abandonada pelo comandante dos déspotas" antes mesmo que disparassem os tiros, depois que os revoltosos entraram de madrugada aos gritos "aterradores". Nessa batalha, o governo perdeu seis homens, os revoltosos conseguiram muito cartuxame e quatro bois. Está no diário a reveladora notícia de que tinham vindo "de Vicente Ferreira de Paula 11 homens no dia 27 de abril de 1849", mostrando uma porosidade entre os grupos que dividiam as matas (homens que mereceram a anotação específica do escritor do diário) e a atividade guerreira praticamente ininterrupta por um ano. O jornal justificou a publicação do diário para mostrar o desânimo nas fileiras liberais, mas deixou transparecer muito mais do que isso: revelou a dimensão ampla da luta, assim como a presença de ideais. Ao leitor seria fácil perceber que não era uma guerra feita sem princípios políticos. Depois de perderem o combate de Penderaca no dia 17 de janeiro de 1850, deixando seis homens mortos e carregando 14 feridos, o major Laurindo Justiniano registrou uns versos:

\footnotetext{
Não sinto perder no campo

A doce vida presada

Só sinto ver perseguida

A chara pátria adorada

Não temo gemer nos ferros

Nem nas medonhas prisões

Só sinto ver como escravos

Brasileiros, cidadãos

(...). ${ }^{27}$
}

Apesar de todo o esforço para justificar o decreto de Honório Leão, a estratégia do prêmio em dinheiro não resultou, ninguém traiu Pedro Ivo ou Caetano Alves. Após o decreto, o pai de Pedro Ivo, o tenente coronel Pedro Antônio Velloso da Silveira, empenhou-se para tentar tirar o filho das matas. Morava na Bahia, para onde tinha sido destacado. Procurou o presidente da província, Gonçalves Martins, e pediu apoio para a missão, já que

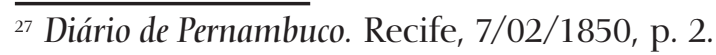


baldo de meios, procurei havê-los de Pernambuco, não os obtive, também não podia partir sem licença (...) correrei a ir salvar a pátria e filho; pois se como cidadão imito a Veturia, como pai não me acho com forças de imitar a Bruto, e confio que V. Ex. me protegerá e me ajudará. ${ }^{28}$

Conseguiu licença de três meses do serviço com meio soldo, passagem paga $^{29}$ e a promessa de que o presidente ajudaria Pedro Ivo e Miguel Affonso a obter anistia. A carta do pai de Pedro Ivo foi lida por Gonçalves Martins aos deputados. Em seu discurso, apelava para o sentimento familiar e dizia que atuara visando pacificar o país, procurando deixar claro que ele não barganhara nada com o pai nem com os revoltosos. Justificava-se, pois corria que prometera anistia geral a todos os envolvidos se Pedro Ivo largasse as armas e viesse com o pai a Salvador. Alguns jornais falaram ainda que o pai, como militar, atuava na Bahia sempre agradando aos conservadores.

Caetano Alves não quis sair das matas. Pedro Ivo cedeu, estava acuado, tinha perdido batalhas, tinha dificuldades para manter a tropa, confiou na articulação do pai e na promessa de anistia a todos. Gonçalves Martins recebeu o grupo em Salvador, ${ }^{30}$ mas convenceu-os a irem tratar da anistia juntos no Rio de Janeiro, cumprindo recomendação do gabinete. Só não contou o motivo real da viagem. Quando entravam na barra, veio a bordo uma força e levou-os à fortaleza de Santa Cruz, presos. No dia seguinte, saiu publicado um decreto de anistia a Pedro Ivo e Miguel Affonso, só que condicionada a deixarem o Império por seis anos. Ambos se recusaram a aceitar tal acordo e Pedro Ivo declarou que tinham se "rendido ao presidente da Bahia, na fé de promessa de uma anistia geral para seus patrícios, não de vantagens pessoais para si. Se disto cuidasse, melhores condições lhe oferecera o sr. Honorio Hermetto".31

\footnotetext{
${ }^{28}$ Pedro Antônio Velloso da Silveira. Carta a Gonçalves Martins. 5 de janeiro de 1850. Publicada pelo Jornal do Comércio, domingo, 12/05/1850, p. 2. Veio na transcrição dos debates da Câmara do dia 11/05/1850.

${ }^{29}$ O Itamontano publicou: "o pae do sr. Pedro Ivo, militar honrado e pobre", 24/05/1850, p. 3.

${ }^{30}$ Vinham com Pedro Ivo: Miguel Affonso Ferreira, Pedro José Alves Correia, Laurindo Justiniano de Mello, Manoel do Nascimento Porto, Agostinho da Silva Guimarães, Bernardo de Almeida Coelho, João dos Santos Lima, Jozé Cordeiro Leal Batinga. E ainda os criados: Joaquim Theotônio de Sant'Anna, Marcolino Joaquim dos Santos, João Jozé, Vicente Ferreira dos Santos e Raimundo Ferreira de Miranda. Havia também um escravo, o Saturnino. É significativo que houvesse cinco criados com eles. Ao que parece, mesmo na guerra havia a presença dos criados - e também um escravo para nove homens, não tendo sido declarado quem era o proprietário deste. Ofício de José Bento da Cunha Figueiredo. 30/03/1850. Ministério do Império. ANRJ, Ijj (9) 253-A.

${ }^{31}$ O Itamontano. Ouro Preto, 24/05/1850. O jornal tinha um correspondente no Rio de Janeiro que não só enviou as notícias como comentou as versões apresentadas pelos jornais da Corte.
} 


\section{A prisão de Pedro Ivo}

A prisão de Pedro Ivo pode ser entendida como o marco final da derrota da Praieira, pois foi naquela trincheira que ele passara de bravo militar a desertor rebelde e foi em nome daquela luta que seguiu armado nas matas por mais um ano. Sabemos que as periodizações em história são construções que obedecem a ordenamentos diversos. Para o governo, quando Honório Leão chegou em julho de 1849 para presidir a província, a Praieira já tinha acabado. Honório, todavia, empenhou-se ativamente na luta contra a "guerra civil", como falava, ou na "nova revolta que assola a província", buscando distingui-la da Praieira. Para muitos historiadores e cronistas, a começar de Figueira de Mello e depois de Joaquim Nabuco, matrizes de tantas leituras, a Praieira acabou em abril de 1849, sendo que já estava condenada depois da derrota da invasão no Recife. Para os que escolheram seguir na luta talvez fosse a mesma guerra.

A prisão em maio de 1850 foi motivo de intensa polêmica entre os conservadores e os liberais na imprensa e na Câmara dos Deputados. Os ânimos ficaram muito acirrados e isso deve ter influenciado no julgamento do imperador ao escrever o bilhete. "Saquaremas e Luzias, nacionais e estrangeiros, ninguém nesta cidade conversa, ha três dias, se não a respeito do sr. Pedro Ivo", escreveu um jornalista sobre o Rio de Janeiro. ${ }^{32} \mathrm{O}$ jornal governista Pedro II, do Ceará, reproduziu o debate na Câmara dos Deputados, quando Justiniano José da Rocha, justamente o panfletário conservador que editava $O$ Brasil e era deputado, fez um discurso para defender a legalidade da prisão e a conduta do governo, e disse: "a oposição tem procurado fazer de Pedro Ivo mais que um Napoleão (...) como se da sua espada dependesse os destinos desse império".33

O tema da prisão dominou os jornais durante os meses de maio e junho de 1850. Os liberais falaram em traição, estratégia covarde, Honório Leão era chamado de despeitado, tirano. Provocava profunda revolta em diversos periódicos liberais do país Pedro Ivo estar incomunicável na prisão da fortaleza de Santa Cruz.

No Correio Mercantil, quase diariamente colunas foram preenchidas, seja reproduzindo os debates na Câmara, seja discutindo a atitude do governo. É interessante destacar as estratégias na disputa e como os jornais iam

\footnotetext{
${ }^{32}$ O Itamontano. Ouro Preto, 24/05/1850.

33 Pedro II. Fortaleza, 22/06/1850, p. 4.
} 
formando seus interlocutores e talvez seus líderes - o Correio Mercantil reproduzia os trechos dos debates parlamentares em que atuavam os deputados da oposição, como Bernardo de Souza Franco e Mello Franco, ${ }^{34}$ transcrevendo cada fala, mostrando quando sofriam boicotes, os requerimentos que traziam, os pedidos de esclarecimentos e as confrontações aos ministros. Depois disso comentavam o que dizia o "honroso Souza Franco" e achincalhavam o ministro que tinha sido evasivo. O Jornal do Comércio destacava as falas dos ministros, a necessidade da ordem; $O$ Brasil publicava artigos opinativos. Comentava também as reações das galerias: "levantou-se S. Ex., os sius partirão de todas as galerias... presentes ardião de ansiedade por ouvir aquelle que se dizia ter pacificado Pernambuco", ${ }^{\prime 5}$ na concorrida sessão que Gonçalves Martins foi tentar se explicar. Os ânimos estavam tensos, nessa semana a polícia tinha entrado nas galerias da Câmara para vigiar o comportamento do público. O Correio Mercantil denunciou com veemência a "escandalosa entrada da policia" naquele recinto. ${ }^{36}$

\footnotetext{
${ }^{34}$ Essa era a Câmara saída das eleições de 1849, conservadora. Francisco Iglesias chamou a atenção, em estudo clássico, que além do único liberal eleito pelo Pará, Souza Franco, vieram outros liberais, os suplentes Mello Franco por Minas, depois Rodrigues dos Santos por São Paulo; em 1851 já eram nove. Cf. IGLESIAS, Francisco. Vida política, 1848/1868. In: HOLANDA, Sérgio Buarque de. História geral da civilização brasileira, op. cit., p. 9-112. Iglésias cita o debate em torno da lei para o julgamento dos crimes militares, "o gabinete empenhava-se no projeto. (...) em 1/set/1851 houve 54 pronunciamentos a favor e 24 contra. Já não havia unanimidade", p. 18. Mais recentemente, estudiosos vieram inclusive a questionar a unanimidade entre os conservadores, documentando as tensões e chamando a atenção para a divisão do grupo. Jeefrey D. Needell ressalta a crise na administração de Honório Leão em Pernambuco que desgostou os conservadores locais. Demoraram a apoiá-lo inteiramente. Por outro lado, os saquaremas no Rio de Janeiro pressionavam pelas eleições e também Eusébio de Queiroz, como ministro da Justiça, mostrava-se insatisfeito com a administração. Ver NEEDELL, Jeefrey. The Party of Order, op. cit., p. 134. Bruno F. Estefanes alertou que o "momento de 'apogeu do Império' sob a égide saquarema tinha sérios pontos de conflito". Para o autor, a reorganização de Pernambuco pós 1848 era só uma "parte da cisão mais profunda entre os conservadores de todo o Império. Ver ESTEFANES, Bruno F. Conciliar o Império, o marquês de Paraná e a política imperial, 1842-1856. São Paulo: Annablume, 2013, p. 212.

35 "O Relógio", cronista que assinava a coluna "Resenha parlamentar" no jornal Correio Mercantil. Rio de Janeiro, 19/05/1850.

${ }^{36}$ Correio Mercantil. Rio de Janeiro, 28/05/1850. Estava em pauta a discussão da Fala do Trono, a prisão do Pedro Ivo, além da candente questão do tráfico. No Jornal do Comércio de 09/07/1850 vemos que na sessão do dia 08/07/1850, quando acabou sendo votado o adiamento da resposta do governo aos "actos praticados pelo cruzeiro inglez", as galerias estavam "topetadas de espectadores. Nos corredores, escadas e arredores da câmara...".
} 
Logo começaram a aparecer matérias na imprensa acusando Gonçalves Martins "o Napoleão de casaca", ${ }^{37}$ de ser conivente com os negreiros e manter "africanos novos" em seu engenho, ${ }^{38}$ neste momento em que o tráfico era ilegal. O prêmio por sua atuação viria em seguida. Foi escolhido para o Senado pela Bahia em 1851 e, em 1852, seria ministro do Império; saiu da Bahia para a política nacional.

Os jornais governistas insistiam na estratégia de esvaziar o debate, desqualificando os oponentes; a principal acusação era serem fomentadores de revoltas. Estava em pauta um esforço dos conservadores para tirar a política da cena, dizia-se que o debate político nos jornais acendia as paixões e já tinha causado muito dano ao país e devia ser evitado sobretudo na época das eleições. Ao mesmo tempo, celebravam novos temas - os melhoramentos materiais, as máquinas - buscando filiar o poder à eficiência da ação. Os jornais liberais, por outro lado, além de denunciar o desrespeito às leis, buscavam dizer que os saquaremas eram negreiros e seguiam com suas fazendas apinhadas de africanos escravizados ilegalmente enquanto alardeavam querer modernizar o país acabando com o tráfico de escravos. ${ }^{39}$

Houve profundas tensões nesse processo. Para os liberais mais radicais, estava em curso "por todo o Norte a paz saquarema, isto é, os assassinatos em grande escala", e denunciavam os que tinham sido vítimas de emboscadas e os "correligionários ameaçados", como o padre Verdeixa, redator do Juiz do Povo, em Fortaleza, Ceará, que escapara por pouco da morte. ${ }^{40}$ Mas, afinal, o

\footnotetext{
37 Era como era chamado pela imprensa de oposição. Ver, por ex., O Grito Nacional. Rio de Janeiro, 2/07/1851, falava nas "illusões de alturas" a que ele teria chegado, "a custa de constantíssimas desonras".

${ }^{38}$ A acusação foi publicada na Bahia, no Argos Santamarense, e transcrita no Grito Nacional, n. 268. Rio de Janeiro, 30/05/1851. Essa acusação não aparecia apenas na pena dos liberais, em carta pessoal a Figueira de Mello do correligionário político do Rio de Janeiro, Bandeira de Mello. Ele conta que o ministro inglês tinha pedido a "demissão de Gonçalves Martins, pelo envolvimento com o contrabando de africanos". Depois completa que ele talvez fosse indicado para o Senado: "o imperador dizem não está contente com elle mas os ministros é que o sustentam". Bandeira de Mello a Figueira de Mello, carta escrita no Rio de Janeiro em 31/01/1851. Seção de manuscritos da Biblioteca Nacional, BNRJ, I-29, 27, 64.

${ }^{39}$ Correio Mercantil, pacotilha. Logo na $1^{\text {a }}$ pacotilha, 10/02/1851, já saía a notícia de que o presidente da Bahia tinha comprado "dois navios dos sete suspeitos de negreiros, cuja entrega era reclamada pelos ingleses, e ainda tinha posto os nomes de Brasilia e Bahiano... Luiz Napoleão no meio dos espinhos, não sahirá com maior sans façon e ligeireza que o presidente da Bahia... escárnio, um calhambeque como o Maria-até-ver passa a ter o nome do Imperio, como se o Brasil fosse todo contrabandista de negros...! Passarei a meter na pacotilha alguma outra cousa que não seja trafico". Importante ressaltar que a posição do Correio Mercantil foi mudando - em 1853 o tom já era outro, apareciam artigos defendendo algumas reformas do gabinete.

${ }^{40} O$ Grito Nacional. Rio de Janeiro, 28/05/1851.
} 
que mais podemos saber do teor do debate político nesses primeiros anos após a Praieira?

\section{O "brado constituinte" dos liberais}

Em debate parlamentar no dia 29 de janeiro de 1850, o deputado Sayão Lobato respondia a Souza Franco, atribuindo o descrédito dos liberais: "pelas ideias as mais subversivas que espalhou na população, pelo brado de constituinte". ${ }^{41}$ O conservador no Rio de Janeiro atribuía a bandeira "aos liberais" de forma ampla, não apenas aos do Norte.

Na carta-manifesto publicada pelos jornais de oposição, Pedro Ivo e Caetano Alves falavam em constituinte. A demanda vinha da Praieira, "os revoltosos tinhão uma idea, a convocação de uma assembleia constituinte: era essa a sua bandeira, o grande facto da revolução", escreveu Urbano Sabino em 1849, buscando imprimir essa marca ao movimento. A demanda aparecera nos artigos publicados em janeiro de 1849 no Diário Novo e está também nos depoimentos dos réus presos, como o de Felipe Lopes Neto (era redator do Diário Novo nesse período), de Henrique Pereira de Lucena, de Leandro Cesar Paes Barreto e de Borges da Fonseca. No primeiro artigo do Diário Novo estava posto que "estamos resolvidos a não largar as armas sem que se chegue ao acordo da convocação de uma assembleia constituinte que trate de decretar aquellas reformas". No Manifesto ao Mundo, escrito por Borges da Fonseca, as reformas vinham especificadas:

Protestamos só largar as armas, quando virmos instalada uma Assembléa Constituinte. Esta Assembléa deve realizar os seguintes princípios: 1 . O voto livre e universal do Povo Brasileiro; 2. A plena e absoluta liberdade de comunicar os pensamentos por meio da imprensa; 3. O trabalho como garantia de vida para o cidadão Brasileiro. 4. O commercio a retalho só para os cidadãos brasileiros; 5 . A inteira e efetiva independência dos poderes constituídos; 6 . A extinção do poder moderador e do direito de agraciar; 7. O elemento federal na nova organização; 8. Completa reforma do poder judicial, em ordem a segurar as garantias dos direitos individuais dos Cidadãos; 9. Extinção da lei do juro convencional; 10. Extinção do actual sistema de recrutamento.42

\footnotetext{
${ }^{41}$ Anais do Parlamento, 28/01/1850, apud QUINTAS, Amaro. O sentido social da Revolução Praieira. Rio de Janeiro: Civilização Brasileira, 1967, p. 71.

${ }^{42}$ Transcrito por MELLO, Jeronimo M. Figueira de. Chronica da rebelião Praieira em 1848 e 1849. Rio de Janeiro: Typ. do Brasil de J. J da Rocha, 1850, p. 194.
} 
O documento tinha a data de $1^{\circ}$ de janeiro de 1849 e era assinado por Borges da Fonseca e outros, como João Ignacio Ribeiro Roma, um dos brigadeiros do Exército liberal que pouco depois perderia a vida em combate. ${ }^{43}$

Nem todos os envolvidos na Praieira concordaram com os termos do Manifesto ao Mundo, como a historiografia já mostrou ${ }^{44}$ e as fontes da época explicitam. Borges da Fonseca era reconhecido como republicano. Mas ele também declarou diversas vezes que respeitaria a decisão da Assembleia Constituinte, caso o regime escolhido fosse a monarquia.

No Piauí, na cidade de Oeiras, foi fundado o Argos Piahuynse no dia 7 de setembro de 1850. Trazia abaixo do cabeçalho, em letras maiúsculas, a palavra Constituinte. E dizia adotar a bandeira pois a "nação quer reformar e curar os defeitos da constituição (...) quer a independencia do poder judiciário, a liberdade da urna, a liberdade do legislativo (...) he porque a nação quer a abolição do tráfico e o governo protege os africanistas...". ${ }^{45}$ Os redatores do jornal em Oeiras não estavam sozinhos. Nesse mesmo 7 de setembro outras províncias do Norte teriam os seus Argos impressos para divulgar a bandeira da Constituinte: Argos Bahiano, Argos Cachoeirano (BA), Argos Cearense, Argos Maranhense, Argos Parahybano e Argos Pernambucano.

Também em Alagoas foi fundado o Argos Alagoano. Todavia, no início, só conseguiram imprimir dois números, pois, como explicaram em nota enviada ao jornal Guaycuru, a tipografia com a qual tinham tratado desistiu da empresa pois foram pressionados pelo chefe de Polícia "que havia prometido no Rio de Janeiro ao Euzebio que nesta província não apareceria folha liberal". ${ }^{46}$ Mais tarde conseguiram uma tipografia que imprimiria também o Tempo, outro jornal liberal. Em suas páginas explicaram que era a missão dos Argos, como folhas constituintes, lutar por essa causa. Buscavam esclarecer que era "pelo sentimento da ordem e da liberdade e não da anarquia" que lutavam. Diziam isso, pois tinham sido acusados de serem mandantes da

\footnotetext{
43 Tomou um tiro na cabeça em uma batalha no dia 13 de fevereiro no Engenho Pau Amarelo, morrendo pouco depois. Para o chefe de polícia que reprimiu a Praieira, era um "homem bem apessoado, algum tanto loquaz, audacioso de maneiras e affeito as desordens e revoluções. Tomou grande parte na revolução que em 1824 promoveram os liberaes (...) em consequencia disso viu-se forçado a emigrar para os Estados Unidos, donde voltou em fins de 1827 (...) Em 1831, 32, 33 e 34 tomou parte mais ou menos em todos os movimentos anarchicos havidos na Provincia", MELLO, Jeronimo, op. cit., p. 349.

${ }^{44}$ MARSON, Isabel. O Império do progresso: a Revolução Praieira em Pernambuco (1842-1855). São Paulo: Brasiliense, 1987, p. 66.

45 Argos Piahuynse. Oeiras, 7/09/1850.

${ }^{46}$ O Guaycuru. Salvador, 26/11/1850.
} 
revolta contra o registro civil há pouco ocorrida, e afirmavam não ter relação nenhuma com o movimento popular, ao contrário, entendiam o censo ser importante para o país. A constituinte era a única esperança e "o papel da oposição não é lutar pelo poder, mas pela constituinte para investigar a causa de tantos males e estabelecer o reinado da justiça", única maneira de acabar com os poderes locais, com o predomínio da violência e da "corrupção em que infelizmente a atualidade baseia o seu plano de governo". ${ }^{4}$

Um ano depois, também no dia 7 de setembro de 1851, surgia na cidade de Natal o primeiro número do jornal O Argos Natalense. Em sua carta de intenções, afirmava o

perfeito acordo em que se acha o partido liberal do Rio Grande do Norte com o da província de Pernambuco e de todo o norte do império, na adoção da bandeira da Constituição, única, em nosso entender, (...) que pode nos salvar do estado de compressão e aviltamento em que nos tem collocado a política saquarema. ${ }^{48}$

Falavam na necessidade de "completa regeneração de nossa Pátria". Parecia ter razão o redator do Argos Natalense, que estampou no n. 13: o "governo vê-se rodeado de Argos, que o espreitão."

No Diário Novo ressuscitado, na primeira edição da nova série, justamente no dia 2 de fevereiro de 1852, essa era a bandeira da volta: "ou a Constituinte será convocada, ou o Brasil se reduzirá a cinzas". Para o Grito Nacional era a possibilidade de união nacional e de reforma em torno de leis legítimas e de d. Pedro II. É dominante na historiografia a ideia de que os liberais não tinham uma pauta nacional. Suzana Cavani Rosas mostrou que o programa dos liberais na Corte foi redigido por uma comissão de quatro políticos de diferentes províncias, São Paulo, Minas Gerais, Rio de Janeiro e Pará. E “assim, contando com o apoio de um influente representante liberal do norte (Souza Franco), os luzias tentavam unir e orientar o seu partido em nível nacional". A autora documentou a força da pauta pela constituinte em Pernambuco e a ausência da ideia no manifesto liberal publicado no Rio de Janeiro. A historiadora esclarece que a bandeira "no Sul foi considerada bastante radical pelos seus correligionários, da mesma forma que a opção pela abstenção eleitoral".49

\footnotetext{
${ }^{47}$ Argos Alagoano. 22/01/1852.

${ }^{48} \mathrm{O}$ Argos Natalense, periódico político e social do Rio Grande do Norte, n. 1. Natal, 7/09/1851.

${ }^{49}$ ROSAS, Suzana Cavani, Da constituinte soberana a conciliação política sobre as bases das reformas: o partido liberal em Pernambuco e o Gabinete Paraná de 1853. Revista de História, n. 170, São Paulo, jan.-jun. 2014, p. 297/298.
} 
Mas é importante destacar que houve diálogo e debate entre os periódicos da oposição do norte e do sul. Vê-se claramente que esses jornais circulavam artigos entre si, citavam-se uns aos outros e marcavam uma "rede" de periódicos da oposição. Pelo Grito Nacional vê-se que a conversa mais afinada era com a imprensa baiana e não apenas de Salvador (aparecem com frequência $O$ Guaccuru, O Século), mas também de Cachoeira - Argos Cachoeirano - e de Santo Amaro - Argos Santamarense - e a pernambucana. Em Minas Gerais, O Itamontano repercutia o debate. Noticiou a prisão dos redatores do Diário Novo em Recife e analisou o momento:

el rei D. Honório designa sempre os revoltosos pelo titulo de bandidos ou salteadores das matas: é sempre o pensamento de fazer crer que a resistência não tem caracter político, desculpa miserável... vandalismo sanguinário da sua portaria das cabeças à premio. ${ }^{50}$

Os redatores do jornal mineiro, ao discutir o andamento da política internacional e local, julgavam viver em "tempos sombrios"; temiam que a marcha da humanidade tivesse perdido o caminho das luzes. Chamavam a câmara de "vestal" pelas eleições "libérrimas, puríssimas".51

Havia interesse dos leitores em acompanhar o que ocorria nas assembleias, tanto a da Corte como as provinciais. Na edição de 8 de novembro de 1851, por exemplo, o redator do Argos Natalense fez uma resenha avaliando os trabalhos da Assembleia Geral naquele ano e dedicou-se a criticar veementemente as novas leis da chibata para a Guarda Nacional, o novo imposto para os jornais e a "lei do sangue", como foi chamada pela oposição a lei que previa a extensão da pena de morte para crimes militares em caso de

\footnotetext{
${ }^{50}$ O Itamontano. Ouro Preto, 2/01/1850.

${ }^{51}$ O Itamontano. Ouro Preto, 12/01/1850.
} 
guerra. ${ }^{52}$ Para discutir contra o imposto da imprensa, ${ }^{53}$ citava o "brilhante discurso do Sr. Montezuma no Senado"; depois, para a "lei do sangue", trazia trechos do discurso de Costa Ferreira e de Souza Franco, além de fazer ampla argumentação. Os deputados iam sendo conhecidos pelo país, assim como as novas leis. Os leitores acumulavam repertório de fontes diversas, folhetos, opúsculos, caricaturas, assim como enchiam as galerias para ver as disputas ao vivo, na Câmara.

Em junho de 1852, em correspondência reservada, o presidente de Pernambuco dava notícia ao ministro da Justiça da preocupação com a instalação em Recife e pela província de "Sociedades com o titulo de Liberal Pernambucana e Constituinte, cujos estatutos encerrao artigos perigosos a ordem publica, havendo filiais". ${ }^{44}$ A Sociedade Liberal Pernambucana "seria a grande responsável pela reorganização do Partido Praieiro após a guerra civil, circulando o seu jornal regularmente de 1852 a 1861".55 Nos Estatutos, no art. 2, já vinha o objetivo demarcado: “a sociedade reconhece como único

\footnotetext{
${ }^{52}$ Era a lei 631 de 18/09/1851, determinando as penas e o processo para crimes militares. O debate foi aguerrido e chama a atenção o diagnóstico que fizeram do tempo em que viviam alguns deputados que buscavam justificar a nova legislação. Para o deputado por São Paulo Silveira da Motta, conservador defensor do governo e da nova lei: "eu encaro a situação atual como perigosa, principalmente pela direção dos espíritos oposicionistas; eu vejo que as instituições sofrem agressões incessantes (...) no nosso paiz prega-se claramente uma forma de governo inteiramente oposta à forma legal (...) uma lei política não se pode defender com argumentos jurídicos, mas com razões políticas". Na resposta ao colega, Rodrigues dos Santos, da oposição, disse: "foi feita a luz", pois o ministro da Justiça tinha ido ao plenário no dia anterior tentar atenuar "a malignidade desta lei, dizer que esta lei não tinha fins políticos, que não era nem podia ser uma nova arma para o governo ferir os partidos políticos" e a declaração do deputado punha tudo às claras. Rodrigues dos Santos fez uma longa e feroz crítica à nova lei, classificando-a como inconstitucional. Cf. Anais da Câmara dos Deputados, doravante ACD, sessão de 30/08/1851.

53 Em 1851, Euzébio de Queiroz e Nabuco de Araújo encarregaram-se de elaborar um projeto de lei para limitar a liberdade de imprensa. Beatriz Momesso atribui o fato à necessidade de "endossar princípios morais e políticos ameaçados", naturalizando a mudança. Ver MOMESSO, Beatriz. Letras, ideias e culturas políticas: os escritos de Nabuco de Araújo (1843-1876). Tese de doutorado, História, UERJ, Rio de Janeiro, 2015, p. 108-111. Um dos pontos centrais do projeto de lei era criminalizar aqueles que incitassem à rebeldia, inclusive por meio de manuscritos. O projeto não foi adiante, mas foi aprovada a lei do imposto, assim como jornais eram fechados e tipógrafos eram recrutados.

${ }^{54}$ Francisco Antônio Ribeiro. Ofício para Eusébio de Queiroz. 8/06/1852. Ministério da Justiça. ANRJ, IJ824. Anexa estava a correspondência do chefe de Polícia de Pernambuco ao presidente. A opinião dele era que as sociedades "não têm causado transtornos mas são perigosas, a propagação de doutrinas revolucionarias... resultados podem ser perniciosos no interior da Província". Grifo meu, pois chama a atenção a percepção do presidente de que havia campo receptivo para tais doutrinas no interior.

${ }^{55}$ ROSAS, Suzana Cavani. Da constituinte soberana..., op. cit., p. 304.
} 
meio possível para conseguir o seu fim a convocação de uma constituinte". A estratégia seria a de "1. Promover por meio da imprensa o desenvolvimento das ideias liberais (...); 2. Organisar associações políticas de conformidade com as leis". ${ }^{56}$ Como esclarece Cavani Rosas, foram fundadas filiais em Goiana, Escada, Rio Formoso, Vitória de Santo Antão, Limoeiro, São Lourenço, Pau d'Alho, Igarassu, Água Preta e no agreste, em Caruaru, “com grande publicidade na imprensa oposicionista da capital".57

Naquele momento, o chefe de Polícia ficou encarregado de vigiar de perto a atuação das sociedades. O presidente não autorizaria o surgimento de novas, mas achava melhor não mandar fechar as existentes para não acirrar os ânimos. Em outra carta, o presidente foi cobrado pelo ministro e precisou se explicar: "o delegado de Água Preta autorizou o funcionamento, obrou sozinho". ${ }^{58}$ Havia uma sociedade liberal pela constituinte justamente em Água Preta, região do Pedro Ivo.

Pedro Ivo já era conhecido em uma escala ampla e, talvez por isso mesmo, inspirasse tanto receio. Ele falou em constituinte e o jornal Correio Mercantil, dos maiores do Brasil, com circulação pelas províncias, publicou o trecho outros republicaram a partir da edição do Correio, como o próprio O Itamontano.

A vigilância sobre a guarnição pedida por d. Pedro II - note-se a consciência de que era preciso vigiar os vigias - conseguiu adiar a fuga de Pedro Ivo por alguns meses. O Diário do Rio de Janeiro, no dia 26 de julho de 1850, publicou uma notícia sobre a decisão do Ministério da Justiça de mandar os presos Miguel Affonso Ferreira e José Correa Leal Batinga para Pernambuco, à disposição do respectivo presidente. O cadete Falcão e Pedro Ivo foram para outra fortaleza, como recomendou o imperador e como era a prática para lidar com presos "insubordinados". Foram para as masmorras da Lage, as mesmas que já tinham abrigado Cipriano Barata e foram celebrizadas por seus escritos de denúncia: ali os homens eram deixados para uma morte lenta.

\footnotetext{
${ }^{56}$ O Liberal Pernambucano, jornal politico e social. Recife, 7.09.1852.

${ }^{57}$ ROSAS, Suzana Cavani, op. cit., p. 305.

${ }^{58}$ Francisco Antônio Ribeiro. Correspondência para Eusébio de Queiroz. 8/06/1852. ANRJ, IJ824.
} 


\section{A fuga}

Na manhã do dia 20 de abril de 1851, domingo de Páscoa, d. Pedro II estava na capela imperial acompanhando as celebrações religiosas quando entrou apressado na igreja um soldado, trazendo um papel nas mãos. Quem primeiro leu e "teve um choque elétrico" foi o ministro da Justiça. "Empalideceu e tremeu, passando-o logo aos seus colegas". ${ }^{59}$ Afinal o temor do imperador tinha se concretizado, Pedro Ivo, o cadete Falcão e outros tinham escapado da prisão, de onde saíram em plena luz do dia.

O Correio Mercantil falou do "desacorçoamento" dos ministros, especialmente Manoel Felizardo e Tosta da Marinha. Pedro Ivo teria deixado presos na cela onde estava os guardas responsáveis pela vigilância e saído em uma embarcação. O Grito Nacional publicou:

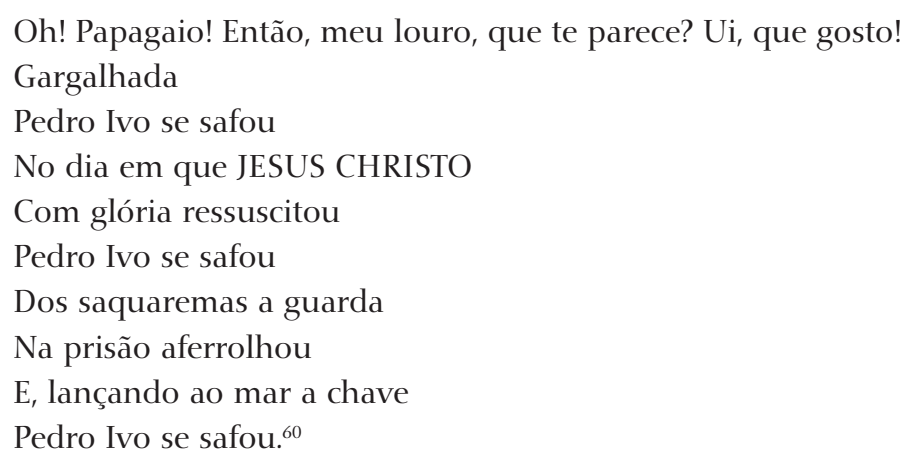

Todos os esforços foram feitos para descobrir o paradeiro de Pedro Ivo - em vão. O jornal divertia-se publicando as diferentes versões para a fuga, assim como as hipóteses sobre onde ele estaria - desde lutando ao lado de Rosas, até vivendo nas coxias do teatro. O homem ia virando mito.

A notícia circulou rapidamente pelas províncias. No Grito Nacional lia-se que no Recife choraram nas ruas e foram muitas as comemorações. Contavam também que o artigo completo sobre a fuga, publicado no dia 24 de abril, foi impresso avulso na Bahia e "teve extracção de 4 mil exemplares". ${ }^{61}$ Em Salvador houve um grande baile promovido pelos liberais para celebrar

\footnotetext{
${ }^{59} \mathrm{O}$ Grito Nacional. Rio de Janeiro. 24/04/1851, primeira página.

${ }^{60} \mathrm{O}$ Grito Nacional. Rio de Janeiro. 14/05/1851, p.4

${ }^{61}$ O Grito Nacional. Rio de Janeiro. 14/05/1851, primeira página.
} 
"a nobre e corajosa evasão do Immortal Pedro Ivo", ocasião em que Francisco Muniz Barreto ${ }^{62}$ compôs um soneto improvisado que terminava assim:

\author{
Muito pode a divina Liberdade! \\ Muito - em seu prol - da Santa Cruz à terra \\ Promette o REDEMPTOR da humanidade! \\ Pedro Ivo o porvir da pátria encerra \\ Raio - solto a punir a iniquidade \\ Tremão de vê-lo, ao fuzilar da guerra. ${ }^{63}$
}

\title{
A notícia chegou às matas
}

No dia 16 de maio de 1851 o diretor da recém-criada Colônia Militar Leopoldina, capitão João da Gama Lobo Bentes, escrevia ao conselheiro José Bento da Cunha Figueiredo, na época presidente de Alagoas. No ofício, alertava: "os Cabanos que já hião amansando tornão-se já athivos com a noticia da fuga de Pedro Ivo". No mesmo dia, mais tarde, completava: "sou obrigado a asseverar a V. Excia que a noticia da fuga de Pedro Ivo começa já a produzir os efeitos que se deve esperar". ${ }^{64}$ E seguia pedindo mais homens, munição e armamentos.

É muito significativo que ele tenha usado as expressões "amansando", lembrando animais sendo domesticados e ao mesmo tempo "ativos" - atributo dos cidadãos, aqueles que podem agir, influir, votar. Importa ressaltar que a notícia chegou rápido às matas, aos povos, aos cabanos que mostravam ter suas redes de conexão e de informação sobre o que se passava na capital do Império.

No local de estabelecimento da colônia já circulavam soldados e guerreiros há muito tempo. Duas colônias foram ali instaladas para tentar modificar a feição das matas, uma em Pernambuco, ao lado do riacho do Mato,

\footnotetext{
${ }_{62}$ Para Sacramento Blake, "foi um dos maiores poetas do Brasil, como repentista não me consta que alguém o excedesse". Em 1855, publicou um livro de poesias, Clássicos românticos. Nascido em 1804 em Jaguaribe, alistou-se voluntariamente aos 18 anos para lutar nas guerras da independência, lutou ainda na Guerra da Cisplatina, chegou a segundo tenente no Exército. Em 1838, voltou para Salvador e foi nomeado primeiro escriturário da Alfândega da Bahia, posto em que se aposentou. BLAKE, Sacramento. Diccionario bibliographico brasileiro, vol. 3. Rio de Janeiro: Imprensa Nacional, 1895, p. 56/57.

${ }^{63}$ O Grito Nacional. Rio de Janeiro. 30/05/1851. O Guaycuru também publicou o poema, mas quase um mês depois, no dia 28/06/1851.

${ }^{64}$ João da Gama Lobo Bentes. Ofício ao presidente da Província de Alagoas. 16 de maio de 1851. Arquivo Público de Alagoas, doravante, APA, caixa 160.
} 
outra em Alagoas, na beira do rio Jacuípe. Vicente Ferreira de Paula circulara na região por quase vinte anos, mas àquela altura estava preso. Água Preta era a base de Pedro Ivo antes da Praieira, foi ali que treinou seu exército formado por caboclos, pardos, escravos fugidos e índios. Caetano Alves, seu maior companheiro, era considerado pelo governo como "sucessor de Vicente de Paula", o que deve indicar tanto sua origem popular quanto seu carisma e capacidade de liderança.

Havia os índios que lutaram ao lado dos rebeldes, como Mauricio de Barros Rego. O governo tentou cooptar o índio Maurício e a sua gente de Jacuípe em 1849 mas ele respondeu: "das autoridades locais de Porto Calvo melhoramento algum se pode esperar para os povos desta Província", 65 recusando a oferta. Mauricio foi morto no final de 1849 no campo de batalha; lutou por nove meses junto com Pedro Ivo e a sua morte foi comemorada pelo governo, vista como uma virada importante nos rumos da guerra. ${ }^{66}$

Houve grupos de indígenas que lutaram ao lado do governo. Honório Leão declarava que na "guerra civil 120 índios de Cimbres foram excelentes soldados e prestaram bons serviços" ${ }^{67}$ Nas guerras do Jacuípe, em 1846, o "caboclo Salazar", líder dos índios do Cocal, tinha sido fundamental apoiando as tropas do governo. Mas o presidente conservador José Bento de Figueiredo avaliava desapontado em setembro de 1849:

\footnotetext{
${ }^{65}$ Mauricio de Barros Rego, capitão mor, ao presidente da província Antonio N. Aguiar. Acampamento em Água Preta, 27 de fevereiro de 1849. O presidente em seu ofício para o ministro da Guerra disse que a letra da carta de Maurício era de Pedro Ivo, "segundo foi reconhecido por pessoas que tem dela conhecimento". Atribuíam ao branco capitão do Exército a prerrogativa da opinião própria e visão política (considerada insolência). A grafia não me pareceu a mesma - mas as cartas atribuídas a Pedro Ivo e que estão anexas por vezes eram também forjadas. É difícil saber ao certo. Ministério da Guerra. Alagoas. ANRJ, IG (1) 97.

${ }^{66}$ O general Coelho escreveu em relatório ao presidente da província: “a sua morte traz grande utilidade, não só por ter desaparecido um inimigo realmente terrível, como porque é provável que os índios se retirem". 23 de novembro de 1849. In: Revista do Arquivo Público, vol. 5, Recife, 1948, p. 658. O jornal Diário de Pernambuco publicou o ofício do mesmo general comandante das armas, "chefe de grande monta, já pelo seu genio turbulento, já pela prática que tinha daqueles lugares, já finalmente pela influência que exercia sobre os de sua raça, os quaes he muito de presumir que se retirem sem a direção de semelhante caudilho". Diário de Pernambuco, 27/11/1849, p. 2.

${ }^{67}$ Honório Leão completava que os índios tinham sido trazidos pelo tenente coronel Torres Galindo e que estavam se queixando de usurpações em suas terras do Urubá. Honório recomendava que eles deveriam ser favorecidos. Fica claro como os índios tinham ido lutar na expectativa de obter a defesa de seus pleitos específicos, a luta pela terra. Carta escrita por Honório Leão em Recife a José Ildefonso de Souza Ramos. 18/05/1850. Ministério da Justiça. ANRJ, IJ824.
} 
o caboculo Salazar (protegido por quem quer que seja) capitaneando os Indios do Cocal, que a qualquer aceno de desordem se aprezenta armado (...) acabou de praticar no dia das eleições (...). He pois necessario que o Governo me habilite com mais força à destruir essas pequenas republicas.

Ele reconhecia o frágil controle sobre os grupos indígenas que atuavam conforme avaliação do que seria melhor para o grupo e por isso pedia força para os destruir. A linguagem era radical. Nessa carta ao ministro da Guerra, José Bento pedia pela instalação urgente da colônia militar e de "grandes estradas que rasguem as matas". ${ }^{68}$

Assim como Pedro Ivo estava sempre junto de Caetano Alves, Vicente Ferreira de Paula tinha a companhia do alferes Chiquinho, "seu sócio e constante aliado". 69 Também sabemos pouco sobre ele. Sabemos que o "pardo cativo Manoel Antônio" era seu braço direito. Sabemos que tinha seu grupo e "coadjuvava" Vicente, apoiando-se mutuamente com alimentos, informações, armas. Em julho de 1851, poucos meses depois de escrever sobre a chegada da notícia da fuga de Pedro Ivo, o capitão Lobo Bentes enviou para Maceió uma das cartas mais carregadas de emoção, dando conta da morte de dois importantes guerreiros cabanos:

Ao alvorecer do dia 29 seguirão em direção às cabeceiras do Riacho Santa Cruz (...) encontrarão o famigerado Alferes Chiquinho, que resistindo também à voz de prisão que lhe intimou teve a mesma sorte de seo satélite as seis horas da tarde.

Para Lobo Bentes, naquele momento tudo fez sentido, estava "contente por ter prestado este pequeno serviço ao meu Pais e a humanidade", e terminava:

Pelo que se acaba de passar cada vez mais me convenço da imensa importância d'este ponto, para onde o Governo deve incessantemente dirigir suas vistas, e se o mesmo Governo quisesse crear huma outra Colonia no Espinho posso quase que asseverar a V. Excia que as mattas do norte das Alagoas e sul de Pernambuco ficariao inteiramente desinfestadas dessas feras, para cuja extinção tem o Paiz feito tantos sacrifícios. ${ }^{70}$

O vocabulário sem dúvida era forte, identificava haver em curso um projeto maior, nacional, de extinção. Mas não era novo. Era assim que tantas vezes os índios foram referidos: desumanizar, igualar a feras, para justificar o assas-

\footnotetext{
${ }^{68}$ Presidente de Alagoas. Ofício ao ministro da Guerra. 20/09/1849. ANRJ, IG (97).

69 Presidente de Alagoas. Carta ao presidente de Pernambuco. 6/07/1845. Apeje, PP16, fl. 175.

${ }^{70}$ Cap. Lobo Bentes. Ofício ao presidente da província. 31 de julho de 1851. APA, caixa 160.
} 
sinato. O diretor da colônia, quando se referia a "cabanos", parece que não fazia distinção entre os seguidores de Pedro Ivo e os de Vicente de Paula. Tinham uma identidade (atribuída) mais ampla cabana / guerreira que era mister diluir.

A sensação de domínio de Lobo Bentes seria alguns meses depois ameaçada com a perspectiva da volta às matas de Pedro Ivo. O assunto era sério e por isso a carta chegou às mãos do ministro da Justiça Euzébio de Queiroz. O diretor da colônia informava que "corria por certo" que um barco vindo do sul desembarcou Pedro Ivo na praia do Gamella, "e guardado por Caetano Alves, que por prévio aviso o veio buscar com uma escolta bem armada, seguiram imediatamente para as matas do Prata". ${ }^{71}$ Nada mais apareceu sobre Pedro Ivo, tudo indica que ficou ali escondido até o final do ano quando desceu para o Rio de Janeiro onde era esperado por muitos.

\section{A morte de Pedro Ivo}

Após a fuga de Pedro Ivo, as esperanças pareciam estar renovadas. Nada melhor do que celebrar com um grandioso banquete pela "regeneração nacional" o mais do que nunca herói Pedro Ivo. Os organizadores da festa, "nortistas que viviam no Rio de Janeiro", tinham primeiro pensado em restringir os convidados aos filhos do Norte, mas "entenderão depois porém que devião convidar aos Brasileiros em geral". O cronista fazia alusão ao momento de alargamento da pauta liberal do Norte, a constituinte, para uma dimensão nacional? Em todo caso, a ideia nacional tinha um sentido concreto, refletiu-se nas comidas servidas para os cerca de 400 presentes em uma praia escondida em Niterói - desde tacacá no tucupi até churrasco gaúcho, frutas as mais variadas, doces de todo o país. ${ }^{72}$ Também os cozinheiros "havia de todas as cores". O local escolhido era simbólico, a mesma praia onde Pedro Ivo passou oito dias escondido "depois que deixou as masmorras" da fortaleza. Quando o dia estava amanhecendo, uma canoa aproximou-se com um homem remando. Alguém gritou "Pedro Ivo!", e ele "pôs-se de pé, tinha mais de mediana estatura, moreno, queimado de sol, com bigodes

\footnotetext{
${ }^{71}$ Cap. Lobo Bentes. Ofício de 16 de setembro de 1851. O vice-presidente encaminhou para o ministro da Justiça a carta do diretor da colônia. ANRJ, IJ824.

${ }^{72}$ Ver OLIVEIRA, Maria Luiza Ferreira de. As guerras nas matas de Jacuípe. Revista Clio, n. 33.2, Recife, UFPE, 2015. No artigo está o debate que a notícia do banquete despertou - apareceu uma polêmica com os jornais conservadores que afirmavam, baseados em artigo de "RB" no Jornal do Comércio, ou do "Rocha do Brasil", ou Justiniano José da Rocha, que o banquete nunca ocorreu.
} 
pretos". Nem conseguiu por os pés na areia, foi carregado nos braços pelos presentes até o local por entre as árvores onde estava montada a mesa.

Partilhar dos sabores de cada província, celebrando a cultura culinária brasileira, rejeitando um cardápio francês, tinha um sentido político forte. Foram muitos os vivas e os brindes no banquete que dizem começou ao raiar do dia e foi até às 10 da noite. Este relato veio no Correio Mercantil, na $48^{\circ}$ pacotilha do dia 5 de janeiro de 1852 que ainda chamou Pedro Ivo de "o Kosuth pernambucano". Ser comparado àquele que lutara pela liberdade da Hungria, líder da insurreição de 1848 lá e que depois fora derrotado e exilado na Turquia, era certamente uma imagem forte. Uma memória para Pedro Ivo inundada pela política e pelo seu tempo. Completamente oposta da construída pelos conservadores.

A decisão de escolher comidas das diversas províncias do Brasil para servir no banquete de "regeneração do país" no primeiro dia do ano de 1852, sinaliza uma radicalidade presente na disputa política do período que talvez não tenha sido ainda suficientemente avaliada. Houve o desejo de refundação coletiva que passava por um novo pacto político e pela valorização da cultura brasileira, na celebração das diversidades regionais e "dos cozinheiros de todas as cores", um movimento que esmoreceu e reapareceria no país muitas décadas depois.

Na primeira semana de fevereiro, Pedro Ivo embarcaria para uma última viagem. Estava a bordo de um navio estrangeiro quando morreu no dia primeiro de março de 1852, uns dizem indo para Pernambuco ficar com os seus, pois sentia-se fraco, outros dizem indo para a Itália. ${ }^{73}$ Atribuíram a morte a complicações gástricas, doença agravada pelos meses que passou confinado nas masmorras das fortalezas do Rio de Janeiro. Morreu em condições bastante misteriosas aquele que era festejado como a esperança de regeneração do país. ${ }^{74}$ Os jornais liberais lamentaram enormemente a perda,

\footnotetext{
$73 \mathrm{O}$ atestado de óbito escrito pelo piloto da embarcação informa que Pedro Ivo embarcou no dia 8 de fevereiro, domingo, em companhia de um criado. Não diz para onde ia. Diz que no dia 14 queixou-se de asma e forte indisposição. Nos dias 23 e 24, o doente estava com "enchação no estômago e nas pernas". Foi piorando rapidamente. O atestado foi escrito pelo piloto "a pedido do capitão que é illeterato". Alguns dias depois publicaram uma carta de um pernambucano afirmando terem sido assassinados Pedro Ivo e seu criado - ninguém tinha tido notícias do paradeiro do criado.

${ }^{74}$ O Correio da Tarde do Rio de Janeiro de 14/06/1852 dava a notícia apresentando a versão do Jornal do Comércio de que ele estava indo para a Europa e a versão do Mercantil de que estava a caminho de Pernambuco. Não falam o nome da embarcação. Criticam o Mercantil, voz do "partido frenético", por culpar o governo pela morte.
} 
muitos foram os poemas publicados, enviados de diversas partes do Brasil. Um, de Porto Feliz, interior de São Paulo, datado do dia 27 de julho de 1852, terminava assim:

Elle foi pela pátria devotado,

Pela causa sem-par da LIBERDADE

Será pelo Brasil sempre chorado. ${ }^{75}$

Depois de escapar da prisão, de passar por tudo o que tinha passado, Pedro Ivo morria no mar, desaparecia.

\section{A "paz saquarema"}

Durante a chamada "paz saquarema", muitos tombaram ou saíram de cena. Caetano Alves saiu de cena, internado nas matas do Prata. Vicente Ferreira de Paula ficou preso até 1860 sem processo judicial. Honório Leão havia alertado ao Ministério, ao prendê-lo, para o fato de não haver provas contra ele nem processo judicial para a sua prisão. ${ }^{76}$ Estava bem longe de ser o único preso sem processo nas cadeias do Brasil. Isso para ficar apenas nos líderes mais populares que atuaram na região onde foram instaladas as colônias militares Leopoldina e Pimenteiras.

Os jornais liberais e os deputados não ousaram defender Vicente Ferreira de Paula; ao contrário de Pedro Ivo, Vicente de Paula era líder apenas dos caboclos das matas. Mas Rosa, a mulher de Vicente de Paula, veio em 1854 lá do íntimo da mata alagoana até a capital brigar contra a prisão do companheiro. Rosa foi acolhida pelo pernambucano e líder da Praieira Borges da Fonseca, ficou hospedada na casa dele na rua da Saúde, 24. Borges tinha sido condenado à prisão perpétua após a Praieira em 1849 e passou um período em Fernando de Noronha - época em que conviveu com Vicente de Paula. Obteve anistia em 1852.

Se a Corte era para onde fluíam os soldados de todo o Brasil, onde seriam formados os batalhões nacionais, era perto do arsenal das tropas que Borges da Fonseca escolheu ficar, conversando nos quartéis, com os marinheiros

\footnotetext{
75 O Grito Nacional. Rio de Janeiro, 13/08/1852, p. 4.

${ }^{76}$ Em relatório secreto entregue a Ildefonso de Souza Ramos e ao Ministério, Honório Leão explicava que Vicente F. de Paula era "réu de muitos crimes de mortes e roubos; mas não posso informar se a respeito deles existem processos inclino-me a crer que nenhum se formasse". Carta a José Ildefonso de Souza Ramos. 18/05/1850. Ministério da Justiça. ANRJ, IJ 824.
} 
nos portos, "promovendo ajuntamentos", recebendo muitas visitas: "à casa de Borges concorre grande numero de soldados, e especialmente do batalhão de Artilharia". Falava pela república, pela constituinte, "apregoa as doctrinas as mais incendiarias". Como informou o chefe de Polícia, era difícil controlá-lo pois ele era "acessível a qualquer hora do dia ou da noite". Estava sempre de portas abertas. "Borges não perde ocasião de desmoralisar a soldadesca, pervertendo-lhe o espírito com doctrinas anarchicas".77 Por isso, o chefe de Polícia recomendava ao ministro Nabuco de Araújo - que assumiu a pasta de ministro da Justiça do gabinete de Honório Leão em setembro de 1853 a remoção do batalhão de artilharia para algum dos subúrbios da cidade.

Na Paraíba, em 1854, foi fundada uma sociedade radical, a Sociedade Popular Paraibana, criada por Bento José Ferreira Ponteiro, para promover "o estabelecimento do governo republicano, a nacionalisação do comércio a retalho e a liberdade dos escravos". Editavam um jornal, A Matraca, "escripto em estylo repugnante e contendo ideias profundamente anarquichas e incendiarias". O chefe de Polícia convocou Bento Ponteiro intimando-o a "dissolver a sociedade por serem os seos fins contrários ao principio consagrado na Constituição".78 Borges da Fonseca em seu jornal O Republico dava notícia da perseguição ao Matraca e da perseverança de Bento Ponteiro. Os dois tinham lutado e sido presos juntos. Bento Ponteiro também tinha saído das lutas da Praieira. Urbano Sabino anotou que ele era "alferes da Guarda Nacional da Parahiba"79 e que, em maio de 1849, estava preso na corveta Euterpe junto com Jeronimo Villela de Castro Tavares e outros líderes praieiros.

\footnotetext{
${ }_{77}$ Cartas do dr. Alexandre Joaquim de Siqueira, chefe de Polícia da Corte. Carta particular de 28 de outubro de 1853 e de 10 de novembro de 1853. IHGB, Coleção Senador Nabuco, pasta 95, lata 365.

${ }^{78}$ Francisco Xavier Pais Barreto, presidente da Paraíba. Carta particular ao ministro Nabuco, 28 de outubro de 1854. IHGB, Coleção Senador Nabuco, DL 362.46. Explicava para Nabuco em carta escrita no dia seguinte, que "se a sociedade 'Popular Parahybana' e seu digno órgão na imprensa, a Matraca, continuassem podiao anarchisar a província e produsir serias dificuldades para o futuro. Estou disposto, no caso de não cessar a Matraca a mandar prender e processar o seu redactor Bento Ponteiro, que he accusado de diversos crimens e recrutar os mais exaltados do seu circulo. Diga-me francamente o que pensa a este respeito". 29 de outubro de 1854. Grifo meu. Souza Franco questionou em 1850 o ministro da Marinha, Tosta, pela imensa quantidade de recrutas enviados de Pernambuco (e ainda em péssimas condições, o que acabou provocando a morte de muitos), ao que respondeu o ministro: "o que queríeis que eu fizesse com os homens apanhados na revolta de Pernambuco? Deveria mandal-os outra vez para as fileiras dos rebeldes, para de novo virem combater a legalidade?". Cf. ACD, sessão de 31/01/1850.

${ }^{79}$ MELLO, Urbano Sabino Pessoa de. Lista dos cidadãos que se achavão presos em Pernambuco no dia 2 de maio de 1849. In: Idem. Apreciação da revolta praieira em Pernambuco. Rio de Janeiro: Typ. do Correio Mercantil, 1849, p. 341.
} 
No livro de Figueira de Mello vemos que Ponteiro era ourives na Paraíba e na guerra virou major de Brigada, foi preso nas cabeceiras do Cabu, no norte da província de Pernambuco, perto de Igarassú. No dia 31 de março, Borges da Fonseca e o ourives Ponteiro entraram na cidade do Recife lado a lado, escoltados para serem presos. ${ }^{80}$

Figueira de Mello ficou como chefe de Polícia no Recife após a Praieira. Em 1850, publicou a Crônica da Revolução Praieira, espécie de versão oficial da revolta. Envolveu-se na divulgação do trabalho pela distribuição e venda de cópias. Logo na introdução dizia que era um trabalho livre do espírito de partido, "com os olhos fitos somente na verdade". ${ }^{11}$ Em 1852, no entanto, entrou em conflito com o presidente Vitor de Oliveira durante a revolta do registro civil. O presidente, em carta reservada ao ministro da Justiça, pediu pela substituição de Figueira de Mello pois acreditava que ele era dotado "de gênio impetuoso, tendo interesses particulares a promover, e sendo um dos Diretores mais notáveis de uma das parcialidades políticas da Província, obra quase sempre apaixonadamente". ${ }^{82}$ Figueira de Mello insistia na existência de um plano articulado pela oposição para "açular" o povo a não baixar armas enquanto não fosse convocada uma assembleia constituinte.

Para ele, as autoridades precisavam ter "energia". ${ }^{33}$ Figueira de Mello acusou o governo por recorrer a "meios brandos, suspendendo o recrutamento e prisões dos amotinados". ${ }^{84}$ Foi afastado do cargo, mas permaneceu ativo na direção partidária. Nabuco de Araújo trouxe Figueira de Mello para perto de si na Corte. Permaneceram atentos, utilizando recursos diversos. Desmoralizar Borges da Fonseca na imprensa e na Câmara foi um recurso utilizado. O Exército era parte central da nova estruturação do poder e por isso era também fundamental controlar a circulação de ideias nos batalhões - e Nabuco de Araújo ocupou-se disso com a ajuda de Figueira de Mello, como mostra um bilhete enviado ao amigo agora chefe de Polícia:

O nosso espião Bento Joaquim e Chaves quer augmento de pensão VM deve eleva-la a $40 \$ 000$ e recomendar-lhe que não deixe de seguir ao B. O que tem elle dito ou con-

\footnotetext{
${ }^{80}$ MELLO, Jerônimo Martiniano Figueira de. Chronica da Rebelião..., op. cit., p. 391 e 392.

${ }^{81}$ Ibidem, p. 12.

${ }^{82}$ Vitor de Oliveira. Carta reservada ao ministro da Justiça. 13/02/1852. ANRJ, IJ824. Vitor de Oliveira ficou mesmo furioso com Figueira de Mello: "enche de indignação a todo homem imparcial...um cynismo talvez nunca visto em correspondência dessa ordem".

${ }^{85}$ J. M. Figueira de Mello. Ofício ao presidente (mais de dez páginas). 15/02/1852. ANRJ, IJ824.

${ }^{84}$ J. M. Figueira de Mello. Ofício ao presidente. 15/02/1852. ANRJ, IJ824.
} 
tado nos últimos dias? Releva que VM lhe pergunte se o B. he visitado por officiais do Exercito e por soldados. O outro espião o Brito pedio-me $60 \$ 000$ mande dar-lhe. 8 Abril 1855, Nabuco. ${ }^{85}$

O B. (aquele que não se deve nomear?), era Borges da Fonseca. De Recife, das lutas da Praieira, estavam agora Nabuco de Araújo, Figueira de Mello e Borges da Fonseca no Rio de Janeiro. Seguiam na luta. O juiz de direito era agora ministro da Justiça, o chefe de Polícia virou chefe de Polícia na Corte. Posições nevrálgicas na articulação política e do controle social. Borges da Fonseca vivia de seus arranjos (ao menos estava livre depois de tanto sofrer na prisão). ${ }^{86}$ Procurava novos interlocutores e seguia com os seus fantasmas, tantos mortos, outros tantos bem vivos, velhos algozes, usando, naqueles tempos de "conciliação", dos propalados "meios brandos".

É preciso agregar à compreensão das disputas do período o conhecimento de como foi urdida a vitória dos conservadores em campo, no miúdo daqueles anos - e lembrar que na perspectiva de muitos dos envolvidos eram tempos incertos, havia projetos para o país que envolviam expectativas diversas. ${ }^{87}$

\footnotetext{
${ }^{85}$ Nabuco de Araújo. Carta a Figueira de Mello. 8 de abril de 1855. Biblioteca Nacional do Rio de Janeiro, Seção de manuscritos reservados, I-29,21, 164.

${ }^{86}$ Borges da Fonseca mandou cartas da prisão para Figueira de Mello: “De ordinário os homens do poder são surdos, deste mal se há VS muitas vezes queixado e eu me queixo agora de VS no poder a VS mesmo. Estou incomunicável, não ha fundamento razoável para isto, o facto é contrario a lei, oje a incomunicabilidade é a maior violência e quando se me priva da presença de amigos, que me podem informar do estado de meu filho, e a quem não posso abraçar talvez no seu derradeiro instante. (...) esta prova porem é superior ao meu coração, as minhas forças (...) sendo que as revoluções não são brincadeira de creanças, não é oje possível tornar a levantar o povo, a menos que fossemos loucos. O feito está feito, nossa revolução calou no coração do pais, ela vai avante sem ser preciso mais sangue, este é o meu pensamento". Borges da Fonseca a Figueira de Mello. Salão da Cadeia. 23 de agosto de 1849. Manuscritos. BNRJ, I-29-27-52. Em outras cartas reclama que era maltratado pelo carcereiro e denuncia com veemência e indignação outros presos sendo espancados e mortos.

${ }^{87}$ Miriam Dolhnikoff estudou recentemente os debates sobre o sistema representativo nas décadas de 1840 e 1850 e mostrou como houve, além da disputa por projetos, uma disputa por narrativas, pelo lugar dos liberais, "a pecha de defensores do poder local e, portanto, de um certo arcaísmo, acabou por, de alguma forma, aderir ao projeto liberal, como queriam seus detratores - de modo que parecesse que não eram portadores de um projeto nacional. No entanto, tratava-se de acusações de cunho político para tirar legitimidade das propostas que parte dos conservadores combatiam. O que estava em jogo eram projetos distintos de representação". Revista do IHGB, a. 178, vol. 474, n. 15-46, Rio de Janeiro, mai./ago. 2017, p. 45.
} 
A Praieira abrigou projetos distintos ${ }^{88}$ mas daria o tom para a atuação dos liberais em Pernambuco por alguns anos. Havia o legado forte da experiência comum no campo de batalha. Precisavam fazer valer o que tinham passado, talvez por isso a luta pela constituinte se revestisse de uma importância maior. No julgamento de Pedro Ivo, quando foi condenado à morte pelo Conselho Militar em dezembro de 1851, grande parte do debate da imprensa liberal e o esforço do seu advogado Urbano Sabino insistiam que a guerra civil nas matas não era uma nova guerra, mas era a mesma, era ainda a Praieira, pela qual Pedro Ivo tinha sido anistiado

Nesses primeiros anos era ainda muito viva a disputa pela memória da Praieira. A revolta poderia passar a ser o começo de algo, de uma desejada reforma radical com uma Assembleia Constituinte, um novo pacto, um novo começo para a sociedade brasileira ou, como diziam, uma "regeneração". Outro fator a ser observado é que as adesões aumentavam, mesmo dos que não haviam participado da revolta, sinalizando para um crescente consenso de que viviam em "tempos incertos". Esse diagnóstico ia sendo apurado com a insatisfação compartilhada em diversas províncias depois da suspensão da Câmara (é preciso lembrar que o gabinete de 29 de setembro governou sem o Legislativo por mais de um ano, de 5 de outubro de 1848 até dezembro de 1849) ${ }^{89}$ do resultado das eleições "libérrimas" de 1849, do decreto das cabeças à prêmio, da Fala do Trono, da ampliação do Exército, da prisão de Pedro Ivo, do desmedido recrutamento. Eram temas exaustivamente debatidos com indignação em Minas Gerais, no Ceará, em São Paulo, na Bahia, em Pernambuco. Quer nos parecer que a derrota da Praieira colocou os liberais ativamente no debate, promoveu uma ampla adesão a um programa de reformas e ainda articulou os "liberais do Norte".

\footnotetext{
${ }^{88}$ Marcus Carvalho e Bruno Câmara observam que a historiografia recente buscou entender as motivações dos diferentes grupos envolvidos, lembrando que basta uma rápida leitura nos autos do inquérito para ter confirmada a heterogeneidade dos participantes, inclusive com perspectivas ideológicas distintas ou mesmo contrárias ao Partido Praieiro, como era o caso do radical Borges da Fonseca. "A Praieira teve outras facetas, indo além da mera disputa oligárquica. Ela catalisou inúmeras insatisfações (...) o que tem encantado a historiografia, portanto, é essa complexidade da Praieira. (...) Agentes sociais tão díspares que arriscaram suas vidas e bens numa guerra aberta contra o governo". CARVALHO, Marcus \& CAMARA, Bruno. A Insurreição Praieira. Revista Almanack braziliense, n. 8, fórum, São Paulo, USP, novembro 2008, p. 7/8.

${ }^{89}$ Jeffrey Needell chama a atenção para essa janela de atuação que o gabinete obteve. Primeiro, justificando-se pelo domínio dos liberais na Câmara, convenceram o imperador a adiar para abril de 1849 a abertura da Assembleia e, depois, em fevereiro, por causa da Praieira, conseguiram a dissolução da Câmara. NEEDELL, Jeffrey. The Party of Order, op. cit., p. 135.
} 
Nos primeiros anos da década de 1850 discutia-se política e a atuação do governo avidamente, não sobrava espaço para muitos outros assuntos nos jornais. Havia uma politização na sociedade brasileira que escapava aos debates na Assembleia, estava nos clubes políticos das capitais e do interior, nos bailes onde se declamavam poemas inflamados, nos jornais de diversas províncias, nas ruas, praças e cafés. Estava nos quartéis e também nas matas, entre os homens livres pobres, libertos, índios e escravos.

\section{Referências bibliográficas}

ALMEIDA, Luis Sávio de. Memorial biográfico de Vicente Ferreira de Paula, o capitão de todas as matas. Maceió: Edufal, 2008.

CARVALHO, José Murilo de. A construção da ordem, a elite política imperial, teatro de sombras, a política imperial. Rio de Janeiro: Editora UFRJ, Relume Dumará, [1980] 1996.

CARVALHO, Marcus. Os nomes da Revolução: lideranças populares na Insurreição Praieira, Recife, 1848-1849. Revista Brasileira de História, vol. 23, n. 45, São Paulo, 2003, ANPUH. p. 209-238. Disponível em: http://www.scielo.br/pdf/rbh/ v23n45/16526.pdf. DOI: http://dx.doi.org/10.1590/S0102-01882003000100009.

CARVALHO, Marcus \& CÂMARA, Bruno D. A Insurreição Praieira. Revista Almanack braziliense, n. 8, fórum, São Paulo, USP, novembro 2008.

DOLHNIKOFF, Miriam. O pacto imperial, origens do federalismo no Brasil. São Paulo: Editora Globo, 2005.

. Governo representativo e eleições no século XIX. Revista do IHGB, a. 178, vol. 474, Rio de Janeiro: IHGB, maio/ago. 2017, p. 15-46. Disponível em: https://ihgb.org.br/revista-eletronica/artigos-474/item/108562-governo-representativo-e-eleicoes-no-seculo-xix.html. DOI+: http:// 10.23927/issn.2526-1347. RIHGB.2017(474):15-46.

ESTEFANES, Bruno. Conciliar o Imperio, o marquês de Paraná e a política imperial, 18421856. São Paulo: AnnaBlume, 2013.

FERRAZ, Sérgio. O Império revisitado: instabilidade ministerial, Câmara dos Deputados e Poder Moderador (1840-1889). Tese de doutorado, Ciência Política, FFLCH, USP, 2012.

FERRAZ, Paula. O gabinete da conciliação: atores, ideias e discursos (1848-1857). Dissertação de mestrado, História, UFJF, 2013.

HOLANDA, Sérgio Buarque de. São Paulo. O Brasil monárquico, dispersão e unidade. In: Idem. História geral da civilização brasileira. São Paulo: Difel, 1964.

IGLESIAS, Francisco. Vida política, 1848/1868. In: HOLANDA, Sérgio Buarque de. História geral da civilização brasileira. São Paulo, Rio de Janeiro: Difel, 1976, p. 9-112.

MARSON, Izabel Andrade. O Império do progresso, a Revolução Praieira em Pernambuco, 1842-1855. São Paulo: Brasiliense, 1987.

MATTOS, Ilmar. Otempo saquarema, a formação do Estado imperial. Rio de Janeiro: Acces, 1994.

MOMESSO, Beatriz Piva. Letras, ideias e culturas políticas: os escritos de Nabuco de Araújo (1843-1876). Tese de doutorado, História, UERJ, 2015. 
MOSHER, Jeffrey. Political struggle ideology $\mathcal{E}$ state building, Pernambuco and the construction of Brazil, 1817-1850. Lincoln: University of Nebraska Press, 2008.

NASCIMENTO, Luiz do. História da imprensa de Pernambuco, vol. II, Diários do Recife, 1829-1900. Recife: UFPE, Imprensa Universitária, 1966.

NEEDELL, Jeffrey. The Party of Order: the conservatives, the state and slavery in the Brazilian monarchy, 1831-1871. Stanford: Stanford Univ. Press, 2006.

OLIVEIRA, Maria Luiza Ferreira de. As guerras nas matas de Jacuípe. Revista Clio, n. 33.2, Recife: UFPE, 2015. Disponível em: https://periodicos.ufpe.br/revistas/ revistaclio/article/view/24710/19985.

Circulação de saberes e de práticas governativas: caminhos de articulação da política no Brasil, 1845-1860. Revista Almanack, n. 18, Guarulhos, abr. 2018. Disponível em: http://www.scielo.br/scielo.php?script=sci_arttextEpid=S2236-46332018000100248E $\operatorname{lng}=$ en $\xi \mathrm{nrm}=\mathrm{iso}$ DOI: http://dx.doi. org/10.1590/2236-463320181806.

ROSAS, Suzana Cavani. Da constituinte soberana a conciliação política sobre as bases das reformas: o Partido Liberal em Pernambuco e o gabinete Paraná de 1853. Revista de História, n. 170, São Paulo, jan.-jun. 2014, p. 291-316. Disponível em: http://revhistoria.usp.br/images/stories/revistas/170/10\%20-020Suzana\%20Cavani\%20Rosas.pdf. DOI: http://dx.doi.org/10.11606/issn.2316-9141. v0i170p291-316. 